\title{
Understanding of Religious Values As A Means to Prevent Violence in Educational Institutions in Indonesia
}

\author{
TJEPPY \\ Universitas Suryakancana, Jl. Pasir Gede Raya 43216, Indonesia \\ email: tjeppy@unsur.ac.id
}

\begin{abstract}
The difficulty of providing an understanding of the values of religion to students in schools is feared to be one of the causes of the emergence of acts of violence in educational institutions. So the purpose of this article is to analyze the understanding of religious values as one way to prevent violence in educational institutions. This research method is qualitative with descriptive analytic approach, and the type of research belongs to category of library research. Primary data sources are 10 books, while secondary data sources are from relevant journals. The conclusion of this article is that violence occurs in educational institutions must be the government's concern. The number of cases of students persecuting their teachers even some has died is an indicator that religious education obtained is only memorized. Students do not understand the purpose and objectives of learning religious education, and this is also because teachers are unable to provide an understanding of the essence of religious education.
\end{abstract}

Keywords: Violence, School, religious education.

\section{Introduction}

The National Education System according to Republic of Indonesia Law Number 20 of 2003, in Chapter I Article 1 states that education is a conscious and planned effort to create a learning atmosphere and learning process so that students actively develop their potential to have religious spiritual strength, self-control personality intelligence, noble character, and skills needed by him, society, nation and state. Based on this policy, the teaching and learning process should be based on understanding of intact religious values so that students and educators have religious spiritual powers, selfcontrol of intelligence personality, and noble character. The facts about the existence of violence in teaching and learning process that occurs both conducted by teachers or students become one indicator that understanding religious values by teachers and students is still weak, considering that in religious values there is tolerance, patience, clarification to find solution (Iqbal, 2014).

Furthermore, in the Regulation of the Ministry of Education and Culture of the
Republic of Indonesia number 82 of 2015 concerning the Prevention and Control of Violence in the Educational Environment, prevention and overcoming the acts of violence in the education environment aims to protect children from acts of violence that occur in the educational unit or in school activities outside the education unit environment, preventing children from committing acts of violence in the educational unit or in school activities outside the educational unit environment, and regulating the mechanisms of prevention, mitigation, and sanctions for acts of violence in the educational unit involving children, both victims and perpetrators (Harto, 2014).

Based on this policy, schools are required to take preventive measures and also deal with violence. One method proposed in this paper is to understand religious values as a whole. The difficulty of providing understanding of the values of religion to students is due to many factors, namely, the teacher has not been able to apply these values, parents of students who do not support the development of their sons and daughters, unpreparedness of students to receive lessons in school,

Received: 2019-01-29, Revision: 2019-03-07, Accepted: 2019-05-29

Print ISSN: 0215-8175; Online ISSN: 2303-2499. DOI: http://dx.doi.org/10.29313/mimbar.v35i1.4398

Accredited $\mathbf{S 2}$ based on the decree No.10/E/KPT/2019 until 2024. Indexed by DOAJ, Sinta, Garuda, Crossreff, Dimensions 
teaching methods with inappropriate teacher so that students experience saturation (Majid, 2010). This can mean that the teacher has not been able to implement the demands of Article 40 paragraph 2 of the Republic of Indonesia Law Number 20 years 2003 which states, "education and education personnel are obliged to create a meaningful, creative, dynamic and dialogical educational atmosphere."

Violence occurs in many regions in Indonesia in which the government must pay more attention to and correct the weaknesses in providing an understanding of religious education. The assumption is it would be impossible for someone who understands religion as a whole to commit violence. Based on research conducted plan of International and the International Center for Research on Women (ICRW), as many as $84 \%$ of students in Indonesia experience violence in the school environment (Tribun News, 2017). The Study, released in early March 2014, involved 9,000 students aged 12-17 years, teachers, principals, parents, and NGO representatives. The research was conducted in $\mathrm{H}$ anoi (Vietnam), Siem Reap (Cambodia), Sunsari (Nepal) District, Umerkot District (Pakistan), Jakarta and Serang District (Indonesia). The high level of violence in the Indonesian school environment exceeds the trend of violence in education in the Asian region, which is $70 \%$.

Responding to the findings, the Indonesian Child Protection Co m mission (KPAI) stated that the number was actually an iceberg phenomenon and had not represented the fact of violence that actually occurred in the education unit environment, especially the violence experienced by children every day. The KPAI expressed concern over the issue at this year's National Education Day commemoration.

Based on KPAI data, 40 percent of students aged 13-15 years reported having experienced physical violence by peers. While 75 percent of students claimed to have committed violence in school. In addition, 50 percent of children report bullying at school (Nasional Tempo, 2017). Some notes on the occurrence of violence in schools such as elementary School Teachers in Garut Smite Students with Cigarettes Because they cannot count, the teacher slapped students in Purwokerto threatened with 5 years in prison, the teacher who was persecuted by a student in Pontianak still undergoing treatment (Liputan 6, 2017).
According to Fitri (2012), the Child Protection Law explicitly states that every student must be protected from various acts of violence, either by the school manager, education staff and also by his/her friends. If such violence happens, then the school would be blamed because they can not maintain the safety of the children.

Those who commit violence certainly have a religion and have studied religious education. But the values contained in it are not applied, especially in the school environment. There are contradictions with the practice of religious education today because education fails to empower students in mastering theoretical knowledge, appreciation and application in everyday life (Megawangi, 2004). In addition, the learning model in educational system is applied less effectively and efficiently. In accordance with the current reality, the learning process used by religious teachers has been using the lecture method. The teacher explains the learning material using the method of lecturing and students as listeners. This learning method is less effective in giving direction to the search process, understanding, discovery, and application and causes students to feel bored and lazy to learn, so that Islamic religious education is hardly given a meaningful influence in everyday life.

Research related to religious values as a means of preventing violence has been carried out by several researchers including Setiani (2016), who conducted research on Anti-Violence Education for Early Childhood. The conclusion in this study is that antiviolence education basically seeks to answer the problems that have surfaced lately in relation to the increasing prevalence of violence against children both in the family, community, and especially in the educational environment. Therefore, as an effort to maintain and ensure that the development of early childhood goes well and to avoid the acts of violence committed by adults, it is important to apply anti-violence education. In its implementation, anti-violence education presents a system of education that is safe, comfortable, enjoyable, and protected from actions that lead to violence. Next is the research conducted by Mukhibat (2012) entitled Reinventing Islamic Values, Culture, and Pancasila in the Development of Character Education. The conclusion of this study is that the ideal value developed in Indonesian character education consists of religion, culture, and values contained in the Pancasila. 
TJEPPY. Understanding Of Religious Values As A Means To Prevent Violence In Educational Institutions In...

Such character education can be said as an authentic or typical Indonesian character education. There is also research conducted by Sukardi (2017) on Value Education in Overcoming Family Moral Degradation. The conclusion in this article is that families have a role to minimize moral degradation through awareness, instilling and developing values and norms in society. Intensive interaction can create an emotional bond between family members, then the value of education planted in the family has a big influence in minimizing the occurrence of moral degradation in family institutions. Therefore, research relating to religious values as a means to prevent violence in educational institutions is still relevant to be studied. Based on that, the purpose of this article is to analyze the understanding of religious values as one way to prevent violence in educational institutions in Indonesia.

\section{Research Methodology}

This article is in the category of library research. According to Kaelan, library research sometimes has a descriptive and also historical traits including those in religious research. It means library research will face data sources in the form of large number of books that require adequate methods. Thus, in library research, collecting books must be done gradually to make it easier to be processed. The research uses data from various references both primary and secondary. The primary books used as data sources in this study amounted to 10 books that examined the education of character, Islamic, moral, multicultural, and Pancasila. The secondary data consists of journals relating to education. These data are collected by documentation techniques, namely by reading (text reading), studying, and recording literature related to the problems discussed (Zed, 2004).

Next is the data analysis technique. The technique used in this article is the data analysis technique modeled by Miles and Huberman. In this model, qualitative analysis is carried out interactively and continuously until it feels sufficient. According to Kaelan, there are two stages in data analysis techniques in the library research. First, the analysis at the time of data collection is intended to better capture the essence or core of the research focus that will be carried out through sources collected and contained in the verbal formulation of language. This process is carried out aspect by aspect, in accordance with the research map. Second, after the data collection process is carried out, then it is analyzed in the form of raw data that must be determined by each other's relationship. The collected data may not necessarily answer all the problems raised in the study, therefore, it is necessary to re-analyze the data that has been clarified. Data analysis in this model include data reduction, data display and description of conclusions or verification (Nasution, 1998).

\section{Results And Discussions \\ Religious Values to Prevent Violence}

Violence against children has become a global issue and is a serious threat which always increasing from year to year. Violence on children according to Terry E. Lawson includes physical violence, emotional violence, verbal violence, and sexual violence (Ligiana, 2008). Efforts to prevent violence in schools also need to be seriously pursued, one of which is through understanding religious values, considering the mandate of the 1945 Constitution explaining the government's efforts to educate the nation's life starting from increasing faith, piety and noble character (Kartadinata, 2015).

The mandate of the 1945 Constitution Article 31 paragraph (1) states that every citizen has the right to education, and paragraph (2) states every citizen is obliged to attend basic education and the government is obliged to finance it. Subsequently, paragraph (3) affirms that the government undertakes and organizes a national education system that enhances faith and piety and noble character in order to educate the nation's life which is regulated by law. In relation to this policy, human resources in schools must improve their faith and devotion in order to educate the nation's life. The fact that violence still occurs frequently in educational institutions can be interpreted that the policy is not easy to implement because there are problems faced by the school both internally and externally (Mulyasana, 2011).

Understanding of religious values is less a priority both in the school and outside the school. One of the reasons is because the doctrine of religious is "rigid" and lacking in humanism, therefore a review is needed. Conveying inclusive religious values in class as the process of religious education must be done in a moderate way because religion is 
love and religion teaches peace.

For example, in the Islamic perspective, the self-approach to God is the goal of education through science. Science can only obtained by humans through teaching. Someone who has the knowledge, takes advantage of that knowledge and uses it for others is like the sun shining on him and also shining on others while he still shines. Knowledge will also bring to religion, a faith for someone who needs it so that knowledge will provide quite large benefits and considerable influence (Arifin, 2000).

As rahmatan lill'alamin, according to the mission carried out by the prophet Muhammad 'Shalla Ilahu 'alayhi wa sallam' peace be up him, Islamic teachings revealed by Allah SWT. to be used as a guide for all humans to achieve happiness in the world and in the hereafter. Thus, Islamic law is universal for all humans on earth and can be applied in every nation and country.

All Islamic teachings (aqeedah, sharia, and morals), aim to free humankind from various shackles of mental-spiritual illness and stagnation of thinking. It regulates the behavior of human actions in an orderly manner so as not to fall into the humiliation and backwardness and achieve happiness in the world and in the hereafter. Synchronity and integrity of these three aspects can be seen in the universality of Islam with its mission as a mercy for all humanity (Zuchdi, 2008).

The perfection of religious teachings is seen in its universal and flexible nature and require the creation of a life balance between worldly and spiritually, physically and mentally. A good worldly life must be used as a medium to achieve a good spiritual life. Conversely, a good spiritual life must be used as a medium to fulfill physical life that is good, legal, and lawful. Therefore, religion is a dynamic life force. It is also a code that appropriate and side by side with nature and covers all aspects of human life.

Based on the above study, the model for understanding religious values to prevent violence in educational institutions takes into account the following: Educating actions themselves. The act of educating means all activities or actions from the attitude taken by education when caring for students. In other terms, guiding attitudes or actions, providing educator to assist students towards the goal of Islamic education. Thus, whoever the teacher is, he/she must give an example of a good attitude. The number of cases of violence committed by the teachers shows their inability to become an educator and a good example for students. Teachers should live out religious values by showing patience and educate students as the most important subject in education with full responsibility.. This is due to the educational action held to bring students to the goals of Islamic education that they aspire to. The number of cases of students persecuting their teachers even some have died as an indicator that religious education obtained is only memorizing. Students do not understand the purpose and objectives of learning religious education; and this is also because teachers are unable to provide an understanding of the essence of religious education. Mulyasana (2011) describes the good character of students in 15 indicators: ffaith and ffaith in allah, fear of God, be simple and fair, beneficiary for others, love to seek knowledge, hard worker, pattern to look for ridho (bless) from Allah SWT; love God and prophet, being generous, have a stable soul (not anxious or too concern over a loss or being ungrateful for what they have, and become a source of peace for others, his/her words and deeds do not harm others, like to remind each other and being care, being tolerant, forgiving and connecting people, to become a pious human being as well as society. The trait of forgiving that must be possessed by students will emerge if it has been exemplified first by parents of students and also educators. Therefore. this is not an instant process but rather needs a pilot process from various interested parties.

The Basics and Objectives of Religious Education. The foundation and source of all Islamic education activities carried out is to form students to become adults who fear Allah and possess Muslim personalities. Islamic education's purpose is to form a whole complete person. Long before the Law Number 20 of 2003 concerning the National Education System was implemented, General Guidelines of State Policy (GBHN) has always set its national education goals towards the formation of whole complete people. The formation of a whole complete human in the perspective of Islam: "O believers, you enter into Islam as a whole, and do not follow the path of Shaytan, in fact, he is your real enemy (Q. 2: 208). A believer who will believe in the holy verses of the Koran by verbally speaking (cognitive), convincing with the heart (affective) and practice in life 
TJEPPY. Understanding Of Religious Values As A Means To Prevent Violence In Educational Institutions In...

(psychomotor).

The opposite of "whole" is "broken/ incomplete". Therefore, it is known as the term "integral person" (integrated personality) and "split personality". In the Muslim community, a split personal figure is known as a hypocritical human being because he/she has no value and attitude in his heart of what he/she says and does. Therefore, Allah SWT said softly: "And do not follow the path of Shaytan, in fact the Shetan is your real enemy". Educator. An educator/teacher is the subject who carries out religious education. This educator has an important role for the ongoing education, whether or not he/she has a big influence on the results of religious education. In the field of humanity, professional educators serve as a substitute for parents, especially in the field of increasing the intellectual abilities of students. Professional teachers become facilitators to help students transform their potential into abilities and skills that develop and benefit humanity. Educators must be able to show a patient attitude as parents want.

Parents. The importance role of parents is to influence the personal formation of their sons and daughters. Parents who are unable to guide their sons and daughters can have a person who is able to live up to religious values. From several factors that contribute to violence, the role of parents is closely related to it. The importance of parental awareness in anticipating crime on children can be anticipated by becoming good parents. There are a number of roles parents can play in preventing violence, including the act as drivers to encourage children to be confident and brave in fighting the crime. Lack of appropriate religious education can be solved by parents by acting as educators and communicators where they educate and conduct two-way communication with children on how to prevent violence. Globalization of information is also closely related to the role of parents and they can act as child supervisors and role models (Parjono, 2005).

\section{Optimizing Religious Values through Religious Education in Preventing Violence in Educational Institutions}

There are several efforts that can be done in fostering peace through religious education including curriculum preparation, role models in religion, learning processes that include interaction and environment that reflects religious values, and the formation of Peace Love Student Groups in schools.

First, the curriculum as a design of education has a fairly important position in the whole process of education. It determines the implementation and the results of what to be achieved in education. Therefore, curriculum preparation must pay attention to what it can provide for education, in general, to function optimally. So far, our education has experienced a reversal of curriculum changes that actually lead to improving the quality of education (Kaelan, 2011). But, sometimes educators themselves do not understand that curriculum concept. Take an example of the 2013 curriculum that contains core competencies with an emphasis on spiritual, social, knowledge and skills competencies. There needs to be an understanding of the curriculum concept itself either ontologically, epistemologically, and axiologically. Religious education curriculum should focus on this matter as a serious concern in the education process: giving understanding, awareness, and the ability in interacting with fellow believers of different religions (Istanto, 2007).

Second, educators are a noble profession because it strives to form a complete human being who has knowledge, faith and piety, skills and competencies. Educators are not only fulfilling the need of knowledge, but more than that, such they form a human person with noble character, good manners and ethics. In Islam, this is known as akhlakul karimah. It indicates that educators must have good attitudes and behavior and be able to become agents of religious education for moral formation. Al Ghazali as quoted by Arifin (2000) emphasizes on improving the attitudes and behavior of educators in educating, such as a) The teacher should treat students like his own children; b) The teacher does not expect wages from work assignments; c) The teacher should give advice to his/her students; d) Teachers must encourage their students to find useful knowledge; e) Teachers should become model of good examples that captivate the students to do the same behavior; f) Teachers must teach according to the level of ability of the students; g) Teachers must practice their knowledge because they are role models and idols for the students; $h$ ) The teacher must be able to understand the mental and soul of his/her students; i) Teachers must be able to educate faith in the personalities of their students so that their minds are subjected to religious teachings (Toufiqoh, 2007). 
Religious education teachers should set an example in respecting adherents of other religions in worship, communication, and the attitude of everyday life. Religious teachers must be the pioneers of a peaceful life (Lickona, 2000). Therefore, coaching the value of peace also relies on the readiness of the educator/teacher who will deliver the material of religious education in the class. Through tolerant, harmonious, and peaceful educators, it is expected to produce tolerant and peaceful students.

\section{Learning Process, Interaction, and Educational Environment}

A good learning process will determine the success of education. In Religious Education, the process must also contain religious values. Religious values can be conveyed through an understanding of the six worlds of meaning, namely: 1) Symbolic meanings include language, symbols, cues, etc; 2) Empirical Meanings of develo ping theoretical abilities and facts about religious life; 3) Aesthetic meanings include beauty values in religion; 4) Synnoetics meanings pertain to feelings, impressions, appreciation, and deep awareness of religious values; 5) The meaning of ethics regarding moral, noble behavior, and responsibility aspects; and 6) Synoptic meanings related to profound meanings about things that are spiritual in nature (Lewis, 1996).

The process of learning religion cannot be separated from the implementation of religious values. This needs to be emphasized in fostering a peaceful life through religious education. Religion must be the controller of the attitude of students in the process of religious education so that the learning process becomes meaningful. Likewise in learning interaction that should reflect religious values because good interactions are very important in religious education. In the teaching and learning process, the interaction between educators and students are quite dominant in the context of transfer of knowledge and values (Lickona, 1999). These interactions can be done through communication, motivation, reinforcement, and attention/attitude. If such interaction has gone well and has religious values, it will support the creation of an educational atmosphere or environment that reflects religious values. Educators, students, administrative staff, and even school guards and security officers are important elements in creating a good environment for education and fostering religious values. This interaction must reflect an attitude of respect and respect for differences. Do not underestimate and play down the role of others, so that mutual respect will grow well since the learning process.

Dadang (2002) states that there are three poles in the everyday lives of the students, namely: family, school, and society, as shown in figure 1 .

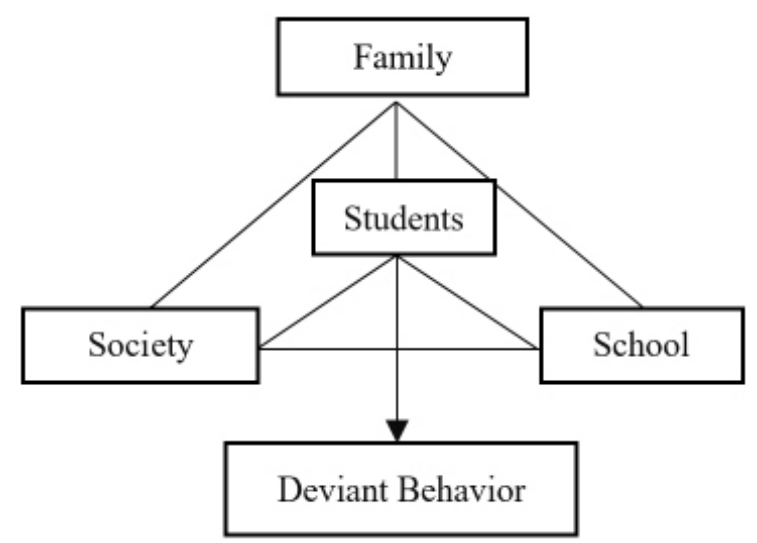

Figure 1. Students' Environments

If there is a deviant behavior of students, what often happens is the attitude of each pole that blames each other. For example, parents at home (family) blame the school (teacher) or blame the community, and vice versa. If we study honestly, the error actually occurs at each pole and there are no independent factors (poles) because one pole related to each other.

Furthermore, the educational environment is an important factor in education. Majid (2010) outlines six environments that have an influence on education and the formation of good attitudes and characters. He mentioned, in addition to the personal factors concerned, there were at least six elements contributed to the development and formation of the characters, namely parents, playing environment, social environment, school environment, working environment, and national environment.

This is similarly conveyed by Lickona (1973) who emphasized the important role of the environment in the cultivation of moral values. According to him, the educational environment such as school must prepare an environment that emphasizes good values and nurtures them as a shared awareness. In the practice of Religious Education, all educational environments are considered important as a determining factor in the success of education. The development of peaceful religious life is largely determined 
TJEPPY. Understanding Of Religious Values As A Means To Prevent Violence In Educational Institutions In...

by environmental factors supporting peaceful and tolerant attitudes and behaviors.

\section{Forming Peace Love Student Groups}

The values of harmony and peace that are taught in the classroom in some subject matter are only mere information without any effort to make students appreciate and apply the harmonious and peaceful in their interaction process. Therefore, the step that can be taken is to create a joint activity program in the school which focuses on fostering life peace, mutual respect, and respect for differences (Jinguang, 2003). In addition, the school can form a Peace Loving Group in each class containing representatives from certain tribes, religions, groups or communities. This group can become a miniature of peace in the school environment as well as contribute to providing a continuous understanding of the importance of life that upholds the values of harmony and peace to fellow students, even to the surrounding environment in an extracurricular program. Another way is by controlling and minimizing the actions of intole rance in the school environment, admonis $h$ the wrong things, and resolve problems themselves peacefully (Yusuf, 2013).

\section{Conclusions}

The importance of religious education is not only limited to being accepted as a subject that must be accepted by students, but all parties from parents, educators, principals, students, the environment must be able to appreciate the religious values they have learned so that students and educators can become tolerant and forgiving person so as to prevent violence in school. Breaking the chain of violence in schools requires a lot of synergy from parents, teachers, principals, other school officers, school committees, local education offices, and communities.

This conclusion is relevant to what Soelaeman (1978) stated that religious values are one way to prevent violence in Educational Institutions. This means that moral education must create a religious culture in the school environment accompanied by the strengthening of the moral field of study. Therefore, awareness of moral and religious education must be intensified and sustainable in three important elements of family, school and society.

\section{References}

Arifin, H.M. (2000). "Filsafat Pendidikan Islam". Jakarta: Bumi Aksara.

Dadang, H. (2002). "Dampak Penyalahgunaan narkoba Terhadap Remaja \& kamtibmas". Jakarta: Dharma Bhakti.

Fitri, A. Z. (2012). "Pendidikan Karakter Berbasis Nilai dan Etika di Sekolah". Yogyakarta: Ar-Ruzz Media.

Hari Pendidikan KPAI 84 Persen Siswa Alami Kekerasan di Sekolah. (2017, August 8). Nasional Tempo, p. 11.

Harto, K. (2014). Pengembangan Pendidikan Agama Islam Berbasis Multikultural, Jurnal Al-Tahrir, Vol. 14, No. 2, pp. 411-431.

Istanto, B. (2007). "Pentingnya Pendidikan Moral Bagi Generasi Penerus". Yogyakarta: FIP UNY.

Iqbal, M.M. (2014). Pendidikan Multikultural Interteligius: Upaya Menyemai Perdamaian dalam Heterogenitas Agama Perspektif Indonesia. Jurnal Sosio Didaktika, 1(1), 89-98.

Jinguang, L. (2003). The Tolerance and Harmony of Chinese Religion in the Age of Globalization. Procedia-Social and Behavioral Sciences, 77(2), 205-209.

Kaelan. (2001). "Pendidikan Moral Pancasila". Yogyakarta: Penerbit Paradigma.

Kartadinata, S. (2015). "Pendidikan Kedamaian". Bandung: Remaja Rosdakarya.

Kekerasan di Sekolah. (2017, May 29). Liputan 6, p. 17.

Kekerasan Anak di Sekolah Semakin Memprihatinkan. (2017, November 23). Tribun News. p. 16.

Lickona, T. (2000). Talks About Character Education. ProQuest Education Journal, 16(1), 27-43.

Lickona, T. (1973). The Return of Character Education. Jurnal Education Leadership, 51(1), 72-87.

Lickona, T. (1991). "Education for Character Education: How Our School Can Teach Respect and Responsibility". New York: Bantam.

Lewis, K. (1996). "Character Education Manifesto". New York: Boston University.

Ligiana, N.L. (2008). Peran Orang Tua dalam Pencegahan Kekerasan Seksual pada Anak Sekolah Dasar di Kota Bandung.

Majid, A. (2010). Peranan Pendidik dalam Upaya Membentuk Karakter Peserta Didik. Jurnal Pendidikan Karakter, 2(2), 58-77.

Megawangi, R. (2004). "Pendidikan Karakter, Solusi Tepat untuk Membangun Bangsa". Jakarta: IHF dan BP Migas. 
Mukhibat. (2012). Reinventing Nilai-Nilai Islam, Budaya, dan Pancasila dalam Pengembangan Pendidikan Karakter. Jurnal Pendidikan Islam, 1(2), 247-265.

Mulyasana, D. (2011). "Model Pengembangan Pendidikan Karakter". Bandung: PPS Uninus.

Nasution. (1998). "Metode Penulisan Naturalistik Kualitatif". Bandung: Tarsito.

Parjono. (2005). "Pendidikan Nilai-nilai Moral". Yogyakarta: MKU UNY.

Republik Indonesia, Undang-Undang Nomor 20 Tahun 2003 tentang Sistem Pendidikan Nasional.

Setiani, R.E. (2016). Pendidikan Anti Kekerasan Untuk Anak Usia Dini: Konsepsi dan Implementasinya. Golden Age: Jurnal IImiah Tumbuh Kembang Anak Usia Dini, 1(2), 39-56.

Soelaeman, MI. (1978). "Pendidikan dalam
Keluarga". Bandung: Diktat kuliah UPI.

Sukardi, R. (2017). Pendidikan Nilai: Mengatasi Degradasi Moral Keluarga. Prosiding Seminar Nasional Pendidikan FKIP UNTIRTA, 305-315.

Toufiqoh, R. (2007). "Pentingnya Pendidikan Moral". Yogyakarta: FBS UNY.

Yusuf, H.A. (2013). Promoting Peaceful Co-Existence and Religious Tolerance through Supplementary Readers and Reading Comprehension Passages in Basic Education Curriculum. International Journal of Humanities and Social Science, $3(8), 20-31$.

Zed, M. (2004). "Metode Penelitian Kepustakaan". Jakarta: Yayasan Obor Indonesia.

Zuchdi, D. (2008). "Humanisasi Pendidikan: Menemukan Kembali Pendidikan yang Manusiawi". Jakarta: Bumi Aksara. 